\title{
From Vienna, Prague or Poland? The Effects of Changing Reporting Patterns on the Ceremonial News of Transylvania, $1619-58$
}

\section{Virginia Dillon}

Located in the crook of the Carpathian Mountains, the principality of Transylvania was on the edge of European Christendom, outside of the postal networks through which most news was transmitted, yet still intermittingly involved in wider European affairs. After a successful rebellion against the Habsburgs from 1604-6, Transylvania established itself as largely autonomous, though it remained under Ottoman suzerainty, and was governed by a series of martial, Reformed princes elected by a diet. Three of these men conducted military campaigns which were of particular interest to the newspapers of the day. The most famous is Gábor Bethlen who led a series of marches against Emperor Ferdinand I I during the Thirty Years War, the first of which, from 1619-21, was the most successful. During these years Bethlen marched as an ally of Frederick, Elector Palatine and king of Bohemia, and was elected king of Hungary and named godfather to Frederick's son. However, after the disaster at White Mountain left Bohemia with little hope, Bethlen made a separate peace with the Emperor, giving up his claim to the title of Hungarian king in exchange for land and recognised freedom of religious practice. This action was mirrored in some ways by a succeeding prince at the end of the Thirty Years War. György I Rákóczi marched into Hungary from 1643-5 as an ally of Sweden and France, and though he was not greeted with as much attention and did not achieve as much success as Bethlen, he did make peace with the Emperor along similar terms. Twelve years later, from 1657-8, his son, György II Rákóczi, attempted an invasion of a different region, the PolishLithuanian Commonwealth, as part of the series of conflicts now known as the Northern Wars. Though his march alongside Charles X Gustav of Sweden achieved success in the first months, the prince could not gain enough Polish support and so retreated by the end of the summer. He was not only unsuccessful in claiming the Polish crown, but provoked the ire of the Ottoman Porte with his ambition, and the Turks marched into Transylvania to reinforce their authority. The following year saw two other men, Ferenc Rhédey and Ákos Barcsai, elected to the position of prince of Transylvania under the persuasion of the Porte.

(C) VIRGINIA DILLON, 2016 | DOI 10.1163/9789004277199_037 
Instead of attempting to follow the news of this principality over a 40-year period, this chapter offers an analysis of three periods when Transylvania was most involved in wider European affairs, from 1619-21, 1643-5 and 1657-8. For these three periods the news reports from all extant issues of the Germanlanguage newspapers are considered. There are few reports from the principality itself, but the military and political manoeuvres of the Transylvanian princes during the Thirty Years War and the Northern Wars were included in reports from Vienna, Prague, Leipzig, Venice, Breslau, Elbing, Thorn and many other locations. ${ }^{1}$ Each reporting location included news of Transylvania according to a particular motivation, whether it was to promote an ally, impugn an enemy or reveal an approaching threat. While the reporting location's perspective affected many aspects of what news was included and what language was employed, this chapter looks specifically at the news of ceremonies, i.e., presents, parades, banquets and formal proclamations of praise.

To what measure news of ceremony appeared is a factor not only of what events occurred, whether an election, baptism or the conquest of a city, but also what reporting locations were carrying the news. Each reporting location presented its own agenda in reporting the ceremonial news, whether it was an ally in Prague hoping to aggrandise a new king in a similar political situation, an enemy in Vienna stressing the prestige of its own court, military posts in the Hereditary Lands and Poland presenting the capable leader of a strong army, or a Hungarian diet legitimising a newly elected ruler. Where the news came from affected what news was reported and how it was communicated.

1 A note on naming: if there is a common English name for a city or region (e.g., Vienna, Prague, Cracow), that will be used. Otherwise, German names and spellings are used within the news analysis in order to be most consistent with the sources. The present day name for each city included is as follows: Breslau (Wrocław, Poland), Brünn (Brno, Czech Republic), Danzig (Gdańsk, Poland), Elbing (Elbląg, Poland), Eperies (Prešov, Slovakia), Fülleck (Fil'akovo, Slovakia), Glatz (Kłodzko, Poland), Glogau (Głogów, Poland), GriechischWeißenburg (Belgrade, Serbia), Kaschau (Košice, Slovakia), Klausenburg (Cluj-Napoca, Romania), Komorn (Komárom, Hungary and Komárno, Slovakia), Königsberg (Kaliningrad, Russia), Lemberg (Lviv, Ukraine), Marienburg (Malbork, Poland), Neuhäusel (Nové Zámky, Slovakia), Neusohl (Banská Bystrica, Slovakia), Nikolsburg (Mikulov, Czech Republic), Ofen (Buda in Budapest, Hungary), Petrikau (Piotrków Trybunalski, Poland), Pilsen (Plzeň, Czech Republic), Pressburg (Bratislava, Slovakia), Stettin (Szczecin, Poland), Thorn (Toruń, Poland), Tyrnau (Trnava, Slovakia), Zips (Spiš, Slovakia), Znaim (Znojmo, Czech Republic). 


\section{Reporting Patterns in the German Language Newspapers}

The first evidence of a German language newspaper is from Strasbourg in 1605, and while the next fourteen years saw six other newspapers founded in the cities of Wolfenbüttel, Frankfurt, Berlin, Hamburg and two unknown locations, the real explosion in German newspaper publishing came with the Thirty Years War. ${ }^{2}$ In the opening years of the war, from 1619-23, at least 13 newspapers were begun in cities such as Vienna, Stuttgart, Cologne, Güstrow, Danzig and Königsberg, inspired not only by the sudden influx of news to report, but also the expansion and improvements made to the postal network. ${ }^{3}$ Despite the destruction and economic depression which accompanied these decades of European conflict, the postal system continued to improve, in large part due to the efforts of the Swedish military, with the result that the cities of Hamburg and Leipzig became as integral to the communicating of news as the political and economic centres of Vienna, Venice or Cologne. ${ }^{4}$ After the Peace of Westphalia was concluded in 1648 , the German princes gained more internal autonomy, and, particularly in Prussia, continued this process of expanding and improving postal communication. ${ }^{5}$

The format of these newspapers makes them particularly suited for an analysis of differing reporting language based on location. First, they include reports from a wide range of locations with no overarching editorial voice, no one in the printing office organising the incoming news into a narrative. Each story retained the perspective of the news writer of the city or town from

2 For more on the Strasbourg newspaper, see Johannes Weber, 'Strassburg 1605: The Origins of the Newspaper in Europe', German History, 24.3 (2006), pp. 387-412. The standard bibliography for seventeenth century German newspapers is Else Bogel and Elger Blühm, eds., Die deutschen Zeitungen des 17. Jahrhunderts, 3 vols. (Bremen: Schünemann Universitätsverlag, 1971-85).

3 This expansion is considered in detail in Wolfgang Behringer, Im Zeichen des Merkur: Reichspost und Kommunikationsrevolution in der Frühen Neuzeit (Göttingen: Vandenhoeck \& Ruprecht, 2003). Also referenced in Wolfgang Behringer, 'Communications Revolutions: A Historiographical Concept', German History, 24.4 (2006), pp. 353-5; Wolfgang Behringer, 'Veränderung der Raum-Zeit-Relation. Zur Bedeutung des Zeitungs- und Nachrichtenwesens während der Zeit des Dreißigjährigen Kriegs', in Zwischen Alltag und Katastrophe. Der Dreißigjährigie Krieg aus der Nähe, ed. Benigna von Krusenstjern and Hans Medick (Göttingen: Vandenhoeck \& Ruprecht, 1999), pp. 46-7.

4 Paul Arblaster, 'Current-affairs Publishing in the Habsburg Netherlands, 1620-1660, in Comparative European Perspectives', D.Phil. thesis (University of Oxford, 1999), p. 110; Behringer, 'Veränderung der Raum-Zeit-Relation', p. 66.

5 Behringer, 'Communications Revolutions', p. 357. 
which it was dispatched. Additionally, each of these various reports includes a dateline stating the location and date from which the report was sent, such as

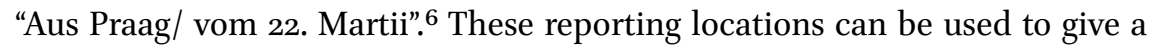
more precise picture of how news communication changed in the periods of $1619-21,1643-5$ and $1657-8$. For each of these periods there are only a handful of newspapers which have at least 50 extant issues, but by looking at the ten cities and regions which are the most frequent reporters in each newspaper, a distinct pattern emerges. As infrastructure improved, the newspapers matured and the wars migrated, the cities and regions which reported the news diversified and spread.

For the years 1619-21 there are six newspapers with at least 50 extant issues, from Wolfenbüttel, Frankfurt, Berlin, Hildesheim and Stuttgart, and they demonstrate a standardised pattern of reporting (see Table 36.1$).{ }^{7}$ Eight of the ten top reporting cities are the same across the newspapers, and they are even fairly consistent in the percentage of news reports they contribute: Prague (usually $13-16 \%)$, Vienna (10-12.5\%), Cologne (7-10\%), The Hague (usually $7-9 \%$ ), Venice (usually $7-8 \%$ ), Rome (usually $6-7 \%$ ), Frankfurt (usually $3 \cdot 5^{-}$ $5 \cdot 5 \%)$ and Breslau (2-4\%). Altogether, the cities which make up the top ten reporting locations for each newspaper account for $60-77 \%$ of the total news reports: two-thirds of the news printed originated in a small number of news centres.

Just twenty years later, from $1643^{-}$, the reporting patterns for the German newspapers are remarkably different as seen in the five newspapers with at least $5^{0}$ extant issues from Leipzig, Erfurt, Hamburg and two unknown locations (see Table 36.2). ${ }^{8}$ Not only had the postal system improved, but newspapers had been founded in London and Paris, and the war itself had spread even more extensively throughout Europe. While the cities of Cologne, Prague,

6 From Aviso Relation oder Zeitung (Wolfenbüttel, 1620: 13) [citations appear in the format: place, year: issue number]. For publishing information see n. 7, below.

7 Aviso Relation oder Zeitung (Wolfenbüttel: Elias Holwein); untitled Zeitung (Frankfurt: Johann von den Birghden); untitled Zeitung (Berlin: Veit Frischmann); Die ... Zeitung/so sich in ... zugetragen hat (Hildesheim: Joachim Gössel); Zeittungen (Stuttgart: Johann Weyrich Rößlin), supplemented by an untitled Zeitung.

8 Wöchentliche Zeitung (Leipzig: Timotheus Ritzsch[?]); Ordinari Wochentliche PostZeitungen ([Erfurt]), also appearing under the title Extraordinari einkommene Zeitungen; Wöchentliche Zeitung auß mehrerley örther (Hamburg: Ilsabe Meyer \& Martin Schumacher), appearing under the names Wochentliche Zeitung, Post-Zeitung, Ordentliche Zeitung; Post/ Hamburger und Reichs-Zeitung (n.p.), also appearing under the names Absonderliche Zeitung, Zu Num ... gehörige ..., Extra-Ordinary Zeitungen/ uber Berlin und anderwerts einkommen, Zu Num ... gehörig, Copia Schreibens; Wochentliche Ordinari-Post-Zeitungen (n.p.). 
TABLE 36.1 Most frequently reporting locations in the newspapers of 1619-21 (percentage of total number of reports in each newspaper) *

\begin{tabular}{|c|c|c|c|c|c|c|}
\hline & $\begin{array}{l}\text { Wolfenbüttel } \\
\text { Aviso }\end{array}$ & $\begin{array}{l}\text { Frankfurt } \\
\text { Postzeitung }\end{array}$ & $\begin{array}{l}\text { Berlin } \\
\text { Zeitung }\end{array}$ & $\begin{array}{l}\text { Hamburg } \\
\text { Wöchentliche }\end{array}$ & $\begin{array}{l}\text { Hildesheim } \\
\text { Zeitung }\end{array}$ & $\begin{array}{l}\text { Stuttgart } \\
\text { Zeittungen }\end{array}$ \\
\hline Extant issues & 54 & 142 & $15^{1}$ & 99 & 53 & $5^{1}$ \\
\hline Total reports & 637 & 1364 & 2284 & 1249 & 1093 & 778 \\
\hline \multicolumn{7}{|c|}{ Reporting location $\dagger$} \\
\hline Alsace & 2.04 & 1.10 & 1.05 & 0.48 & 1.19 & - \\
\hline Amsterdam & 0.16 & 6.89 & 1.93 & 1.84 & 0.18 & 0.64 \\
\hline Augsburg & 0.47 & 0.66 & 2.45 & 2.32 & 1.10 & 0.64 \\
\hline Breslau & 4.08 & 2.20 & 2.15 & 2.24 & 3.48 & $3 \cdot 47$ \\
\hline Brussels & $o .63$ & 2.05 & 0.92 & 0.24 & 0.55 & 0.64 \\
\hline Budweis & - & $0.5^{1}$ & 0.26 & 0.48 & 1.46 & 0.13 \\
\hline Cologne & 8.01 & 10.04 & 8.10 & 7.05 & 9.06 & 8.23 \\
\hline Frankfurt & 5.18 & 0.07 & 3.46 & 5.12 & $5 \cdot 5^{8}$ & 3.60 \\
\hline The Hague & 8.01 & 8.87 & 3.06 & $7 \cdot 93$ & 6.09 & $7 \cdot 33$ \\
\hline Linz & 1.73 & 1.39 & 2.10 & 0.80 & 1.19 & 0.51 \\
\hline Lyon & $3 \cdot 54$ & 1.76 & 2.06 & 1.92 & 2.29 & 3.60 \\
\hline Nuremberg & - & 0.22 & 1.53 & 1.28 & - & 5.27 \\
\hline The Palatinate & 0.31 & 1.54 & 1.62 & 2.08 & - & 1.80 \\
\hline Prague & 13.19 & 10.26 & $15 \cdot 76$ & 14.41 & 17.20 & 12.98 \\
\hline Rome & 7.22 & $7 \cdot 55$ & $4 \cdot 33$ & 6.65 & $7 \cdot 3^{2}$ & 7.07 \\
\hline Strasbourg & 2.04 & 0.22 & 1.23 & 0.96 & 1.46 & 0.51 \\
\hline Venice & 7.85 & $7 \cdot 77$ & 4.90 & 7.21 & 7.87 & $7 \cdot 33$ \\
\hline Vienna & 10.68 & 11.66 & 12.48 & 11.45 & 12.17 & 11.95 \\
\hline Wesel & 0.16 & 1.91 & 0.53 & - & - & - \\
\hline
\end{tabular}

* The ten most frequently contributing cities are in bold, others for comparison in italics.

$\dagger$ The term 'reporting location', in this and other uses, refers to the city or region specified in the dateline of each report.

Vienna, Venice and Lyon are still commonly among the top ten reporting locations, Breslau and The Hague no longer make the list, and Paris, London, Milan, Leipzig and Hamburg are as likely to be among a newspaper's top ten as Frankfurt or Rome. Additionally, the most frequently reporting cities no longer account for the bulk of the news reported. Rarely does one city contribute more than $7 \%$ of news reports and, totalled together, the top ten reporting cities make up less than half of the total reports. 
TABLE 36.2 Most frequently reporting locations in the newspapers of $1643^{-5}$ (percentage of total number of reports in each newspaper $)^{*}$

\begin{tabular}{|c|c|c|c|c|c|}
\hline & $\begin{array}{l}\text { Leipzig } \\
\text { Wöchentliche }\end{array}$ & $\begin{array}{l}\text { Post/ } \\
\text { Hamburger }\end{array}$ & $\begin{array}{l}\text { Wochentliche } \\
\text { Ordinari }\end{array}$ & $\begin{array}{l}\text { Erfurt } \\
\text { Ordinari }\end{array}$ & $\begin{array}{l}\text { Hamburg } \\
\text { Wöchentliche }\end{array}$ \\
\hline Extant issues & 157 & 120 & 133 & 62 & 75 \\
\hline Total reports & 1263 & 1464 & 1328 & 565 & 684 \\
\hline \multicolumn{6}{|c|}{ Reporting location } \\
\hline Amsterdam & $3 \cdot 72$ & 0.14 & - & 1.24 & 0.29 \\
\hline Antwerp & 5.07 & 0.48 & 0.08 & 2.65 & 0.44 \\
\hline Cologne & $3 \cdot 72$ & 6.83 & $9 \cdot 94$ & 4.25 & $6.5^{8}$ \\
\hline Erfurt & - & 2.46 & 6.70 & 0.18 & 1.75 \\
\hline Frankfurt & 1.98 & 4.03 & $7 \cdot 53$ & 0.35 & 5.26 \\
\hline Hamburg & 2.61 & $3 \cdot 55$ & 5.95 & 1.95 & - \\
\hline Leipzig & - & 5.87 & $9 \cdot 34$ & - & $3 \cdot 36$ \\
\hline London & 5.86 & 1.50 & - & $3 \cdot 72$ & 1.75 \\
\hline Lyon & 2.14 & 3.07 & 8.43 & 4.25 & 5.99 \\
\hline Milan & 1.98 & 1.09 & 6.70 & $3 \cdot 54$ & 3.22 \\
\hline Nuremberg & 1.19 & 1.71 & $o .6 o$ & - & 2.92 \\
\hline Osnabrück & 1.82 & 2.60 & 0.15 & 1.42 & 1.02 \\
\hline Paris & $4 \cdot 75$ & 3.89 & 0.15 & 5.66 & 5.26 \\
\hline Prague & 2.85 & $4 \cdot 30$ & $5 \cdot 72$ & 3.01 & $6.5^{8}$ \\
\hline Rhine River & 1.35 & 2.19 & 0.83 & 6.19 & 2.63 \\
\hline Rome & 2.61 & 2.19 & 4.59 & 2.48 & 1.32 \\
\hline Venice & 3.09 & 3.01 & $5 \cdot 72$ & 3.89 & $3 \cdot 5^{1}$ \\
\hline Vienna & 2.77 & $7 \cdot 17$ & 9.19 & 4.60 & $5 \cdot 5^{6}$ \\
\hline Wesel & 0.40 & 0.07 & - & $3 \cdot 36$ & 0.15 \\
\hline
\end{tabular}

* The ten most frequently contributing cities are in bold, others for comparison in italics.

The exception to this pattern is the Wochentliche Ordinari in which threequarters of the news stories come from the top ten reporting cities, dominated by news from the Habsburg hereditary lands and Germany. Each of the other newspapers has also developed its own habit and character in reporting. The Leipzig Wöchentliche is the only one of these newspapers to receive at least $3 \%$ of its news from either Amsterdam or Antwerp. The paper from Erfurt has a large number of reports from Wesel, less than 100 miles away along the Rhine River, as well as the Rhine River itself. The Hamburg Wöchentliche and the Post/ 
Hamburger und Reichs-Zeitung, somewhat predictably, are similar in the cities which account for their top ten reporting locations. The networks of reporting are diversifying, though most are still concentrated in the north-western corner of the continent.

With the newspapers of $1657^{-8}$ the patterns in news reporting shift once again, this time towards the Baltic. Hamburg had become an important reporting centre during the last period, but the Northern Wars and the rise of the Prussian postal network assured its dominant position. The five newspapers from this period with at least 50 extant issues include the Hamburg Wöchentliche, which is nearly perfectly preserved, as well as papers from Zurich, Frankfurt and two from Munich, each of which reports at least $14 \%$ of its news from Hamburg (see Table 36.3 ). ${ }^{9}$ In clear contrast to the reporting patterns of $1643-5$, all of the newspapers except for the Hamburg paper receive at least three-quarters of their news from their top ten reporting cities, with single locations responsible for $10 \%$ or more of the total number of reports.

Though these newspapers often receive a great deal of news from very few locations, which cities and regions account for these few locations alters greatly. Cologne, Hamburg, Paris, Venice and Vienna are often among the top ten, but the percentage of news each city contributes is by no means consistent. Also, there are two distinct characteristics of newspapers developing: those which focus on the new reporting centres along the Baltic coast and those which focus on the older news centres of central and western Europe. The latter category includes the Zurich Relation and the Munich Ordinari, though the Zurich paper seemingly substitutes France for Paris, and Italy for Rome and Venice. The other Munich paper, the PostZeitung, receives more news from the northeastern locations of Berlin, Danzig and Prussia. The Frankfurt Continuation Deß jüngst zwischen beyde Königliche Schwedischen und Pohlnische Armeen zugetragenen Kriegs-verlauffs, as its name suggests, chiefly reports news of the Northern Wars, and the cities which count as the top ten are exclusively Baltic: Hamburg, Danzig, Elbing, Riga, Stettin, Wismar, Königsberg, Marienburg, Thorn, and the castle Gottorf. The Hamburg Wöchentliche, in addition to having the highest survival rate, also demonstrates

9 Wöchentliche Zeitung auß mehrerley örther (Hamburg: Martin Schumacher), also appearing under the names Ordinari Diengstags Zeitung, Wochentliche Donnerstags Zeitung, APPENDIX Der Wochentlichen Zeitung Von Numero ...; Newe Vnpartheysche Zeittung und Relation (Zurich: Offizin Bodmer); Continuation Deß jüngst zwischen beyde Königliche Schwedischen und Pohlnische Armeen zugetragenen Kriegs-verlauffs (Frankfurt: Johann Philipp Weiß), also appearing under the name Absonderliche Relation. Ordenliche Wochentliche PostZeitungen (Munich: Lucas Straub); Ordinari Zeitung (Munich: Johann Jäcklin). 
TABLE 36.3 Most frequently reporting locations in the newspapers of 1657-8 (percentage of total number of reports in each newspaper)*

\begin{tabular}{|c|c|c|c|c|c|}
\hline & $\begin{array}{l}\text { Hamburg } \\
\text { Wöchentliche }\end{array}$ & $\begin{array}{l}\text { Munich } \\
\text { Ordinari }\end{array}$ & $\begin{array}{l}\text { Munich } \\
\text { PostZeitungen }\end{array}$ & $\begin{array}{l}\text { Zurich } \\
\text { Relation }\end{array}$ & $\begin{array}{l}\text { Frankfurt } \\
\text { Continuation }\end{array}$ \\
\hline Extant issues & 311 & $5^{2}$ & $5^{0}$ & 79 & 104 \\
\hline Total reports & 2780 & 336 & 227 & 664 & 500 \\
\hline \multicolumn{6}{|c|}{ Reporting location } \\
\hline Antwerp & $3 \cdot 5^{6}$ & 1.79 & 1.44 & 0.30 & - \\
\hline Berlin & 0.29 & - & 5.05 & 0.60 & 1.00 \\
\hline Cologne & 2.95 & 15.18 & $28.5^{2}$ & 11.90 & - \\
\hline Danzig & 3.13 & 0.30 & $7 \cdot 94$ & 1.66 & 5.00 \\
\hline Elbe River & $0.5^{8}$ & 0.30 & 7.22 & 0.30 & 0.20 \\
\hline Elbing & 4.82 & - & - & 1.66 & 6.80 \\
\hline France & 0.04 & 0.30 & - & 7.08 & - \\
\hline Frankfurt & 3.27 & 6.85 & - & $5 \cdot 72$ & - \\
\hline Gottorf & - & - & 1.44 & 0.45 & 2.40 \\
\hline Hamburg & - & 16.96 & 14.08 & 14.01 & 34.40 \\
\hline Italy & 0.07 & - & - & 8.43 & - \\
\hline Königsberg & 1.62 & $0.6 o$ & 0.36 & 1.36 & 2.60 \\
\hline London & 1.91 & 0.30 & - & $7 \cdot 53$ & 0.20 \\
\hline Main River & 0.22 & - & 2.17 & 0.15 & - \\
\hline Marienburg & 5.65 & $o .6 o$ & - & 1.05 & 10.40 \\
\hline Milan & 1.83 & 3.27 & - & 1.20 & - \\
\hline Oder River & 0.07 & 2.68 & 0.36 & 1.20 & - \\
\hline Paris & 4.64 & 2.68 & 14.08 & $3 \cdot 46$ & - \\
\hline Prague & 2.59 & 4.46 & 0.36 & 2.41 & - \\
\hline Prussia & 0.07 & - & 2.17 & - & 0.20 \\
\hline Riga & 3.24 & $o .6 o$ & - & $0.6 o$ & 3.40 \\
\hline Rome & $5 \cdot 97$ & $7 \cdot 44$ & 1.08 & 1.81 & - \\
\hline Silesia & 0.68 & $7 \cdot 44$ & 0.36 & 7.23 & 0.40 \\
\hline Stettin & 1.47 & - & - & 0.15 & 3.20 \\
\hline Thorn & 2.70 & - & - & $0.6 o$ & 2.80 \\
\hline Venice & $4 \cdot 35$ & 9.82 & 2.89 & $3 \cdot 92$ & - \\
\hline Vienna & $5 \cdot 76$ & 11.31 & 2.17 & 6.33 & 0.20 \\
\hline Wismar & 2.09 & - & 0.72 & 0.45 & 3.20 \\
\hline
\end{tabular}

\footnotetext{
* The ten most frequently contributing cities are in bold, others for comparison in italics.
} 
the most breadth in reporting, with no city contributing more than $6 \%$ of the total stories, and both the older and newer reporting centres counting among the most frequently reporting.

Even if only select years are examined, the reporting patterns of the newspapers of these forty years demonstrate clear changes. At the beginning of the Thirty Years War, from 1619-21, the newspapers were consistent both in the matter of which cities contributed the greatest number of reports and how frequently those reports appeared. Towards the end of the war, from $1643^{-5}$, after the Swedish army contributed to a great expansion of the postal system, new newspapers were founded in a variety of European cities and the war itself had grown to include nearly all of Europe, the reporting habits of the newspapers had changed. During this period, newspapers reported from a variety of cities and there was little consistency in which cities were most likely to appear as the most frequent reporters of the news. Reporting habits changed once again after the Prussian postal system developed and Poland-Lithuania became the major theatre of war; during the years $1657-8$, the cities along the Baltic become increasingly important, led by Hamburg. Newspapers during this period were likely to receive a large portion of their reports from a handful of cities, as in 1619-21, but which reporting locations were most represented was not consistent from publication to publication, as in $1643-5$. These changes in the locations favoured by the newspapers in each period affected how the news was reported, even from areas, like Transylvania, which rarely contributed news reports themselves.

\section{Reporting Patterns within the Transylvanian News Stories}

Not every newspaper during the three periods considered here is as wellpreserved as those described above. In order to better examine all the surviving news of Transylvania, including news within the several newspapers for which few issues survive, this chapter considers individual reports, not entire publications. In addition, news reports which include the same information, using the same language, from the same location, are only counted once, so that particular stories are not given greater weight because they survive in the extant issues of multiple newspapers. When repeating reports are excluded, news from Transylvania is included in 764 distinct news stories from the years 1619-21, 355 stories from $1643-5$ and 479 stories from 1657-8.

The datelines of these 1,598 news reports display patterns of reporting that in some ways mirror those of the newspapers more broadly considered. The only city that consistently contributes a large number of news stories on 
Transylvania is Vienna, which was not only the nearest major political centre but also the capital of the Habsburg emperors that the Transylvanian prince was frequently acting against. While Vienna offers between 136 and 324 news reports for each period, none of the other cities appearing in the datelines (with the exception of Prague in 1619-21) contributes more than 50 reports. However, if these cities are grouped by political and economic regions, rather than considered individually, these reporting regions can more closely rival the news from Vienna (see Table 36.4).

For the years 1619-21, at the beginning of the Thirty Years War, the stories of Transylvania mostly come from the warring powers of Vienna and Prague, but are supplemented by news from elsewhere in the Habsburg Hereditary Lands (including primarily Austria, Bohemia, Silesia, Moravia and Styria) and Hungary (Figure 36.1). For the years 1643-5, at the end of the Thirty Years War, after the Bohemians were defeated and the Swedes had asserted their authority and built their postal system in northern Europe, almost three-fifths of the Transylvanian news came from Vienna, with occasional reports from the Hereditary Lands and the German Lands, primarily from the Swedish postal and military centres at Hamburg and Leipzig (see Figure 36.2). The expansion of the postal network in Prussia meant that news of the Northern Wars in Poland-Lithuania was also carried by the new news centres along the Baltic Sea, including the cities within the Polish, Brandenburg and Swedish lands,

TABLE 36.4 Number of discrete news stories on Transylvania from each reporting region and period

\begin{tabular}{lccc}
\hline Reporting region & $\mathbf{1 6 1 9 - 2 1}$ & $\mathbf{1 6 4 3 - 5}$ & $\mathbf{1 6 5 7 - 8}$ \\
\hline Vienna & 324 & 206 & $13^{6}$ \\
Prague & 235 & 58 & 79 \\
Hereditary Lands & 75 & 8 & 10 \\
Hungary-Transylvania & 65 & 65 & 41 \\
German Lands & 24 & 10 & 38 \\
Poland-Lithuania & 10 & 3 & $15^{8}$ \\
The Baltic & 25 & 5 & 14 \\
Mediterranean & 6 & 355 & 379 \\
Other* & 764 & & \\
Total & & & \\
\end{tabular}

* Includes reports without a location included in the dateline, along with those from the Low Countries and France. 


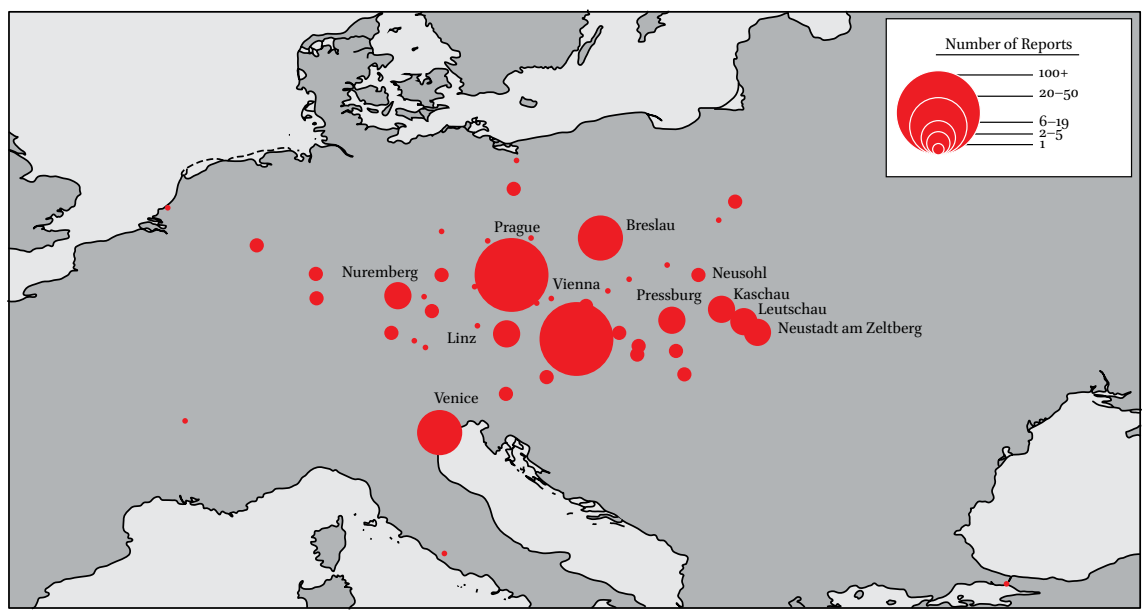

FIGURE 36.1 Map indicating reporting cities for news stories of Transylvania, 1619-21

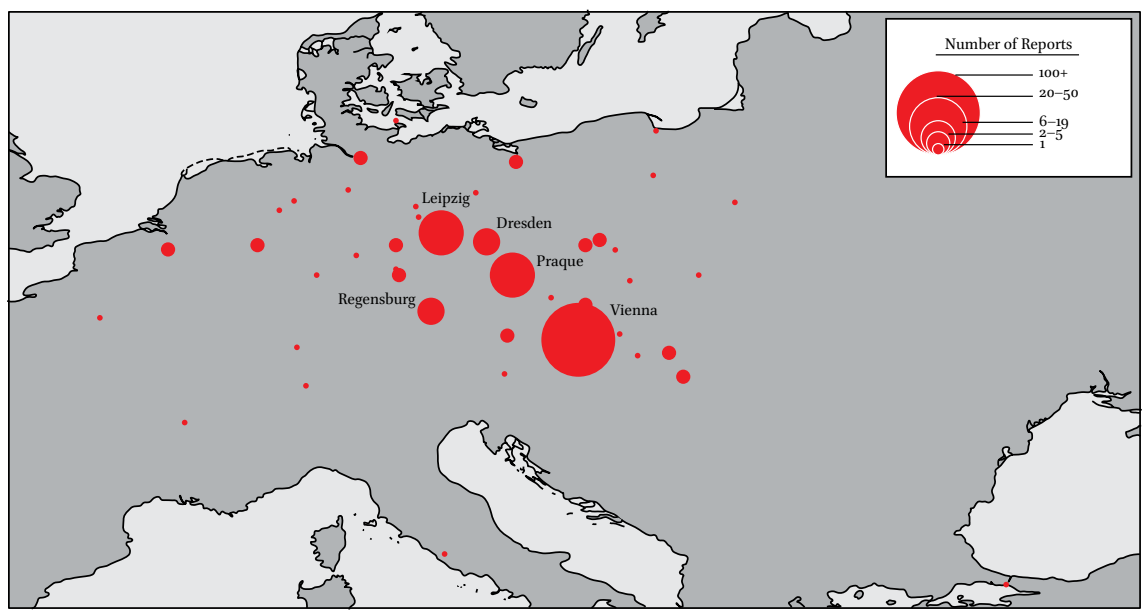

FIGURE 36.2 Map indicating reporting cities for news stories of Transylvania, 1643-5

and, for the first time in 1657-8, more of the stories of Transylvania came from a region other than Vienna (see Figure 36.3). This is also the only period when news came directly from Transylvania itself, with four reports from late 1657 and 1658 primarily concerned with the question of deposing one prince and electing a new one, as well as one report from Klausenburg at the start of 1657 giving news of György II starting his march.

Within the text of the news stories, roughly a quarter reference a further source for the news being related, whether a letter, messenger or report. These in-text 


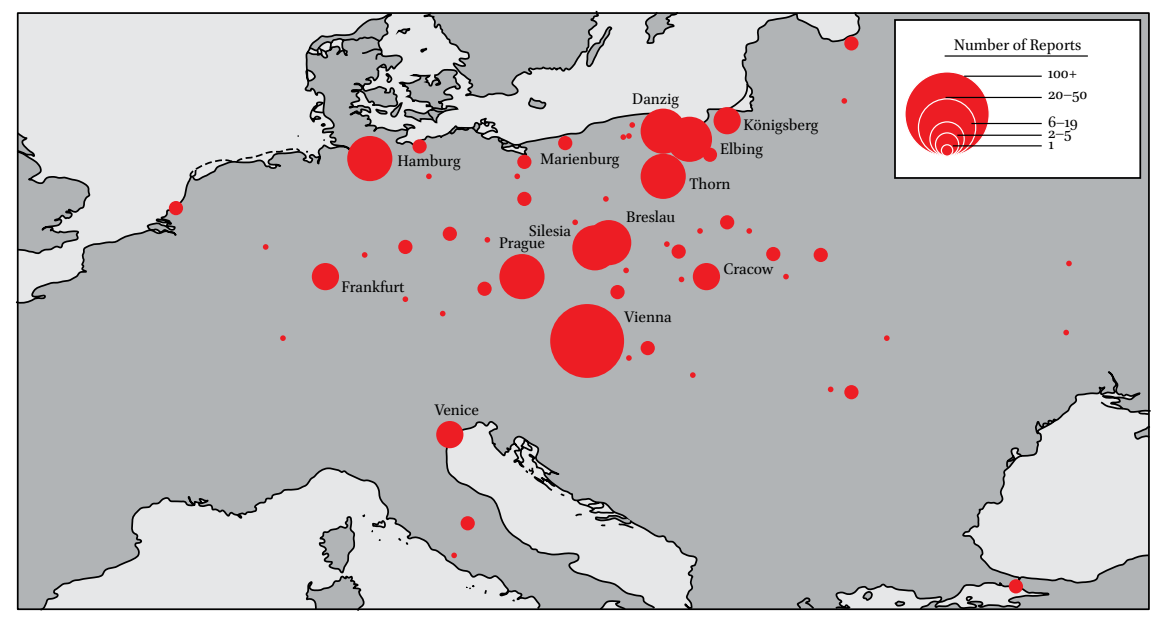

FIGURE 36.3 Map indicating reporting cities for news stories of Transylvania, 1657-8

citations may be used to give greater credibility to the news or to pass the blame for potentially false information, but also give further insight to paths of communication. Among the news stories of Transylvania there are four main patterns of news distribution: from Hungary and Transylvania to the Hereditary Lands, including Vienna and Prague; from Poland to the Baltic and Silesia; from Vienna and later Poland to the German Lands; from the Ottoman territories to Venice and later Vienna. In addition, news often travels within reporting regions, particularly the Hereditary Lands and the Baltic. By combining these two levels of reporting, the information in the dateline and the in-text citations, a fuller sense of how the news of Transylvania was communicated can be seen: not only which cities reported the most often on Transylvania, but from where they received their news.

The city of Vienna is the most frequent reporter of the news of Transylvania and acts as a hub which other reporting regions, particularly the Hereditary Lands and German Lands, cite as the source of Transylvanian news. This city, in turn, receives much of its news from Royal Hungary due to significant historical connections. In the sixteenth century, the medieval kingdom of Hungary had been divided into three parts: those lands held directly by the Ottomans, the principality of Transylvania, and the kingdom of Hungary under the control of the Habsburgs. Many noble Magyar families held lands in both Transylvania and Hungary, and throughout the seventeenth century a desire to reunite the regions remained. With the Reformation, the Reformed Church gained strength among Magyars in both countries, and the Habsburgs' Counter-Reformation measures to strengthen the Catholic Church in Hungary provoked the Transylvanians' 
desire to seize the crown of St. Stephen in order to best ensure the protection of Protestant rights. However, despite some successful efforts, particularly those of Bethlen, the kingdom of Hungary remained with the Habsburgs and continued to act as an important source of news for Vienna. Therefore, Hungary remained an integral source of Transylvanian news not only due to its geographical proximity, but because of the strong political, economic and cultural ties which led to continued Transylvanian involvement in Hungarian affairs, including the marches of both Bethlen and György I.

Of the Viennese news stories of 1619-21, 26 cite news as coming from Hungary, including references to the city of Neusohl where the election of Bethlen as the king of Hungary took place (2), the Hungarian capital of Pressburg (5) and the sites of early military engagements in Kaschau (4), Neuhäusel (2), Komorn (1) and Tyrnau (1). This number also includes the 11 reports which give little detail in the in-text citation besides stating that the news is 'Aus Ungarn' or 'From Hungary'. This pattern continues during György I's march into Hungary at the end of the Thirty Years War. News comes once more from the cities of Pressburg (1), Kaschau (2) and Tyrnau (1), as well as Eperies (1), Fülleck (1) and Zips (1). Furthermore, the reference to news as simply being 'from Hungary' becomes more common, with 23 citations that give little information besides the name of the kingdom.

The importance of this communication from Hungary to Vienna becomes increasingly clear in the years 1657-8 when György II did not invade Hungary, but rather turned his sights on Poland. Even with no action by the Transylvanian prince taking place within Hungary, there are still 36 intext citations to the region from Vienna. These citations only reference a particular city four times (Pressburg twice and Neusohl and Eperies once), but communicate that the news is 'Aus Ungarn' on 32 occasions. Throughout these three periods it becomes clear that while news of Transylvania may have been communicated primarily from Hungary initially because it was the region where the political and military actions took place, it eventually became a settled communication route. News of Transylvania travelled via Hungary to Vienna and then to the newspapers as an established branch of the communications network.

While Hungary was the main source of Transylvanian news for Vienna, it is not the only location cited within the Viennese news stories. News also came from the Hereditary Lands, including the cities of Breslau (2), Brünn (1), Nikolsburg (1) and Eggenburg (1), and, more broadly, Silesia (3), Moravia (2), Bohemia (1) and Styria (1). In addition, news travelled from Transylvania itself. News from Transylvania was primarily communicated by messengers, either from the prince or from Imperial envoys returning to court. In the news stories about Bethlen, there are three references to envoys or letters from the prince, 
four references to news "from Transylvania" and another five references to news relayed by the Duke d'Angoulême, a French envoy who either travelled between Bethlen and Vienna himself or sent a trumpeter to bear his communications. ${ }^{10}$ The news from Transylvania was communicated in a somewhat similar manner in the years $1657-8$, with six citations "from Transylvania" and six to messengers sent by György II. However, the communication from Transylvania to Vienna is not always intentional, as is seen in the years $1643^{-5}$. Of the six references to news travelling from Transylvania to Vienna during this period, five are messengers from György I and the sixth is a letter sent from the prince to the Swedish army which was intercepted and its contents printed.1

Though there was communication between the Transylvanian princes and their sometimes enemies in Vienna, Bethlen was much more likely to send news to his allies in Prague. The city of Prague supplied a large number of news stories concerning Transylvania at the beginning of the Thirty Years War, nearly matching Vienna in output with 124 stories from Prague and 107 from Vienna in 1619, and 164 and 205 respectively in 1620 . However, after Frederick's defeat at White Mountain in November 1620, Prague's reporting of Transylvanian news drops off significantly, with only 21 stories in the whole of 1621 . While Prague continued to be a centre of news reporting in Europe during the other two periods (see Tables 36.2 and 36.3 ), it was no longer a frequent reporter of the news of Transylvania.

For the years when Prague did contribute a large number of reports on Transylvania, in-text citations reference many of the same locations and media that are found in the Viennese reports. News travelled from Hungary on 29 occasions, including stories from Pressburg (10), Neusohl (6) and Kaschau (1). Furthermore, there are 17 messengers or letters arriving from Bethlen. In addition to news from Hungary and Transylvania, there are 39 references to incoming information from other locations in the Hereditary Lands. Many of these items report on military efforts and include 13 letters from the Bohemian camps, as well as reports from Vienna (7), Moravia (5), Silesia (4), the Austrian camps (3) and Brünn (2), among others. Because the Bohemian and Transylvanian forces were allied, stories from Prague frequently contain news from the combined military efforts, as armies anticipated support or moved to meet each other.

$10 \quad$ For examples, see "Auß Wien vom 14. Novembris", Raporten (Cologne, 1620: E); “Auß Wien vom 14. Ditto [Oct.]", untitled Zeitung (Frankfurt, 1620: 55).

11 The intercepted letter: "Auß Wien/ den 2. Dito [Sept.]", Wochentliche Ordinari-PostZeitungen (n.p., 1643: 38). 
Other reports from the hereditary lands in 1619-21, outside of Prague and Vienna, primarily received news of Bethlen from locations in Hungary and Transylvania. Appearing on just one occasion each are intext citations to news from Pressburg in stories from Znaim, Moravia and Eggenburg; from Bethlen and his commanders in stories from Bohemia and the Bohemian camps; and news travelling from Hungary in stories from the Bohemian camps and Breslau. In addition, there are two references to news traveling from Vienna to Linz and two more to news from Poland to Breslau. For the most part, the news of Transylvania in the stories from the hereditary lands comes from the Transylvanians or Hungary, though there is evidence of other regional branches of communication.

The reports of György I's and György II's marches in some ways follow this same pattern, with news travelling from Hungary, Vienna and the military camps. From 1643-5, news travelled from Kaschau and Hungary to Prague (2), Linz (2), Breslau (2) and Ebersdorf (1); from Vienna to Linz (1), Bohemia (1) and Prague (2); and from the military camps in Brünn and Moravia to Prague (1) and Breslau (2). From 1657-8, this continued with Vienna continuing to act as a source of news for Prague (2), Breslau (1) and Silesia (1); Hungary is cited as a source of news for Prague (2) and Bohemia (1); and the Transylvanians as a source for Breslau (1) and Pilsen (1).

However, for the period $1657-8$ there is also a clearly distinct reporting pattern, as stories from the Hereditary Lands not only contain news from Hungary, Transylvania, Bohemia and Moravia, but also frequently from Poland and Prussia. While the news from Poland may appear in stories from Prague (4) and Glatz (1) in Bohemia, the cities of Silesia, situated on Poland's border and sharing economic and cultural ties, are much more likely to cite news from the Northern Wars (see Figure 36.4). Silesia (7), its capital Breslau (10) and Glogau (1) note information coming from Poland and Prussia, the Swedish officers, and the cities along György II's march, such as Cracow and Lemberg. In the year 1657, György II marched into a new reporting region, and while its effects may not be seen in the news gathering habits of Vienna, they are clearly noticeable in the Transylvanian news stories from the hereditary lands.

The communication from Poland to Silesia is part of a larger pattern of news distribution as news travelled from Poland to the hereditary lands and the Baltic. This second major reporting habit only clearly appears in the period of $1657-8$, though there are rare news stories from Poland and the Baltic in previous periods. This is because György II's march occurred after the news centres of Danzig, Elbing, Königsberg, Marienburg and Thorn had become more developed (all of which appear among the top overall reporting locations of $1657-8$, see Table 36.3). These five cities acted as a hub of news transfer, receiving 


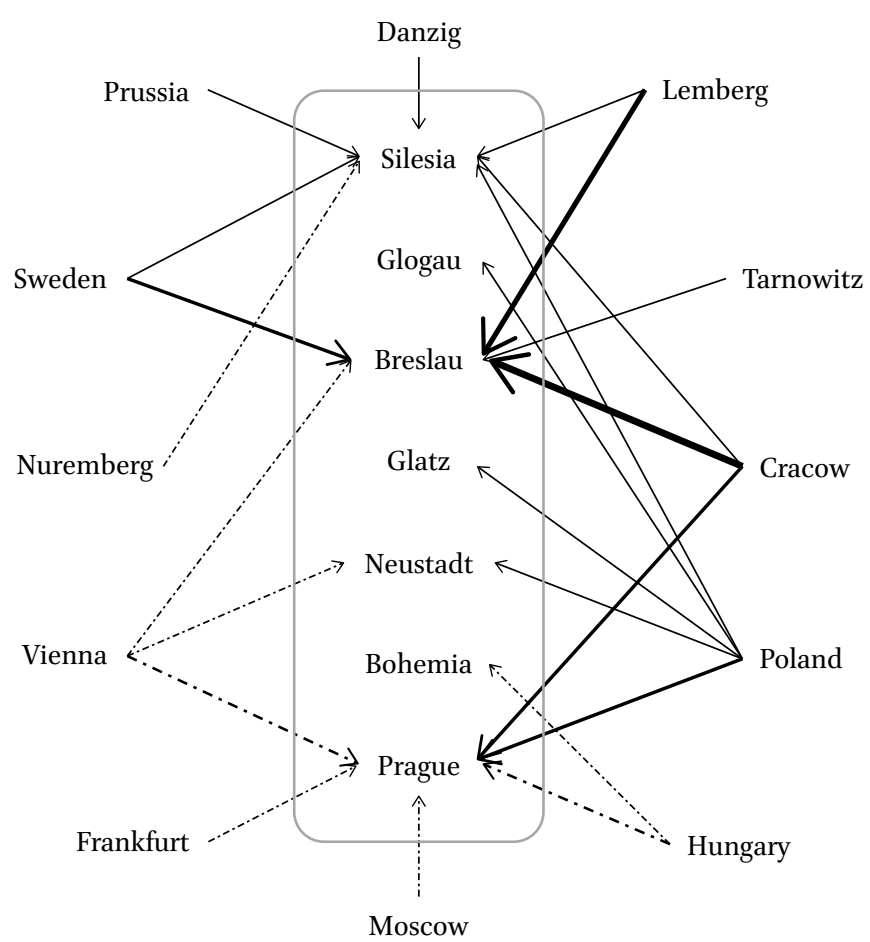

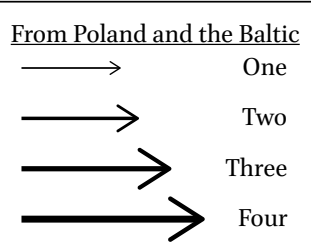

From Other Locations

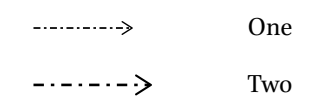

FIGU RE 36.4 Locations cited within the text of stories from the Hereditary Lands, 1657-8

reports from Poland-Lithuania (7), as well as the specific cities of Zamość (5), Cracow (1) and Petrikau (1), and the military camps and commanders of the Transylvanian (5) and Swedish (2) armies. In addition, these cities also sent several reports to each other (see Figure 36.5). Thorn, further upstream on the Vistula River and roughly halfway between Warsaw and Danzig, acts as a point through which information is passed. The city never received news of Transylvania from the cities further north and frequently acted as a source of information for the ongoing war in reports from Marienburg (6), Elbing (4) and Köngisberg (2). Even when the sample is limited to those reports which reference the actions of György II, a rich and complex network of communication within the Prussian cities is apparent.

These are the main means by which news of Transylvania reached the German newspapers: from Hungary and Transylvania via Vienna and Prague and, from 1657-8, from Poland via Silesia or Prussia. There are other reporting patterns of which less evidence remains in the German language reports. News from the Ottoman Empire travelled primarily from Constantinople to 


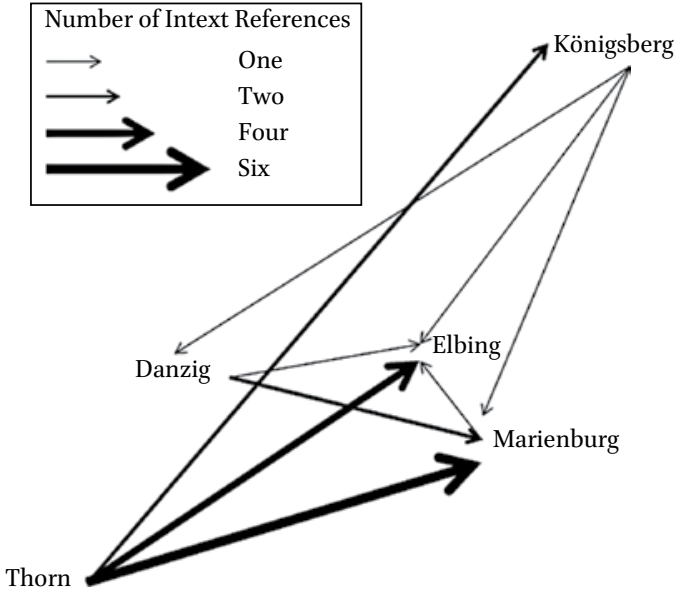

FIGURE 36.5

News transference between the major reporting locations of the Baltic reporting region, $1657-8$

Venice in the years 1619-21 (cited in 9 stories), but in the later periods Turkish news travelled through Vienna: there was news from Ofen (3), Constantinople (2), Griechisch-Weißenburg (1) and the Ottoman Empire more broadly (1) in 1643-5 and from Constantinople (3) and the Ottoman Empire (3) in 1657-8. Additionally, stories from the German Lands often cite locations in the Hereditary Lands as a source of Transylvanian news. This is particularly the case for Vienna, which is cited in reports from Frankfurt (5), Dresden (2), Erfurt (2), Augsburg (1) and Nuremberg (1) for all three periods, but also Bohemia, Breslau and Prague, each cited twice as a source of news in reports from the German Lands. News from Hungary is also included in stories from Regensburg (2), Cologne (1) and Nuremberg (1). The interesting exception to this pattern is the Hamburg news stories, which never reference Transylvanian news as coming from the Hereditary Lands or Hungary, but instead cite Warsaw (5), Danzig (1), Elbing (1) and Poland (1).

Each reporting region relied chiefly on regional or established sources for their news. Vienna received most of its Transylvanian news from Hungary, while for the few years that Prague was an active reporter it was more likely to count news from the military camps or the Transylvanian prince as the source of information. The wider Hereditary Lands were fairly uniform in their reporting habits in 1619-21 and $1643^{-5}$, primarily reporting news from within the same region, though Silesia's close ties to Poland are evident in 1657-8. The cities along the Baltic received news from each other and within Poland. Each of these patterns of gathering and reporting the news betrays a different perspective on the principality of Transylvania, one that can also be seen in the content of the news stories. 


\section{Ceremonies in the News Stories of Transylvania}

The ceremonies which appear in the stories of Transylvania are often marked by more colourful and descriptive language than the other content of the news. Accounts of cities besieged, armies on the move and the dispatching of envoys are occasionally interrupted by descriptions of a procession of men dressed in fine liveries or by details of costly gifts presented to a ruler. Within these news stories, ceremony appears in four major forms: presentations of gifts or banners, processions made into courts or camps, the hosting of another as a guest of home or table and the formal language of oaths and proclamations. In each of these cases, the description of ceremony supplements the news not by adding more essential information, but by giving a more nuanced impression of the events taking place. Because ceremony is, in some ways, nonessential, it reveals the underlying perspective of the reporting region.

Ceremony is represented in the news of Transylvania in both the political and military spheres and is concentrated around four primary concerns. First is that of a country choosing its own leader through kingly and princely elections. The most striking instance is in news from Hungary of Bethlen's kingly election in 1620 , though it is also apparent in the news from Transylvania in the two instances of a new prince's election in 1657-8. The second category is the reporting of ceremonial matters (as defined in the above paragraph) from Transylvania's allies illustrated by the reports from both Prague in 1619-21 and the Swedish military headquarters in Leipzig in $1643-5$. The third category consists of news from the embattled lands themselves, particularly the hereditary lands and Poland, which includes news from conquered cities and military camps containing more martial examples of ceremony. Finally, there is news from Vienna, the headquarters of the power with which the Transylvanian prince was most often at war, which reports ceremonial matters as a way of expressing the political power of the Emperor. However, while each of these four relationships (electing country, ally, invaded country and enemy) recur throughout the three periods, the use of ceremonial description in the news is not consistent. Rather, the relative political strength of Transylvania and the reporting regions affected the degree to which ceremony is a regular fixture of the reports, so that ceremony which is flattering to the Transylvanian prince is evident in Bethlen's Hungarian march, is relatively absent in György I's, but returns when György II invades Poland (see Figure 36.6).

The news stories from 1619-21 contain a great deal of ceremonial news, largely concentrated on Bethlen's greatest political achievement: his election as king of Hungary in 1620 . Of the 15 items of ceremonial news from Hungary, 


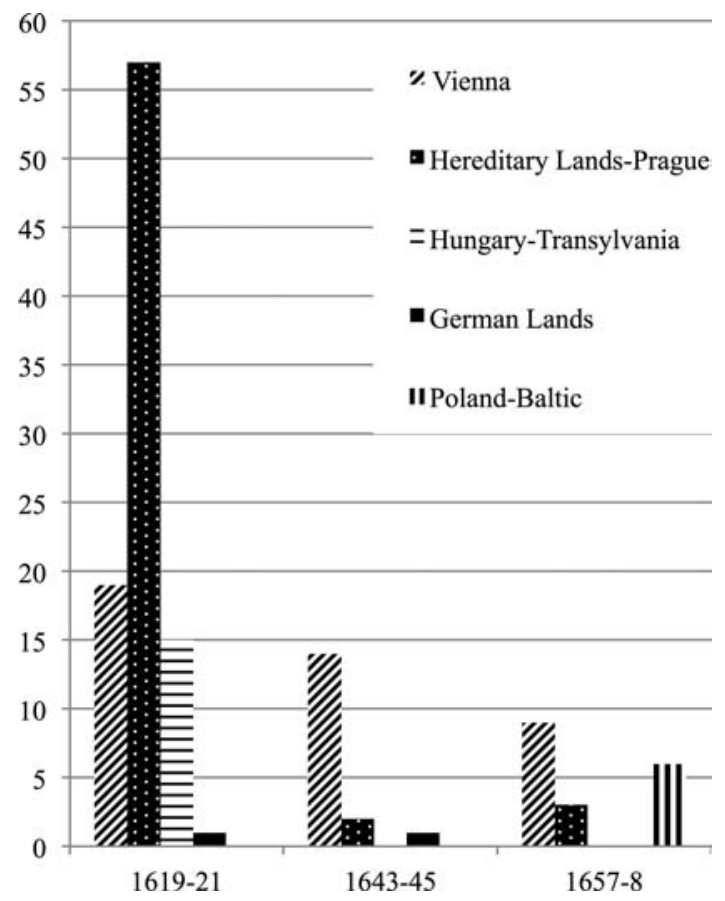

FIGURE 36.6

Number of items of ceremonial news by reporting region and period

nine are used to describe the pomp and finery that surround the diet meeting in Neusohl where Bethlen's election took place. This includes the arrival of Bethlen with his wife, her gentlewomen and 12,00o stately men on horse and foot; a banquet where 200 silver dishes were set before Bethlen's guests, including the Imperial and Polish envoys, the Hungarian palatine and other lords; and 20 Turks on horseback bringing wagons of presents with them. ${ }^{12}$ All of the wealth displayed by the Transylvanian representatives and the gifts given to Bethlen further supported the legitimacy of his election by presenting him as already possessing the appearance, prestige and situation of a king.

In many ways, this is the role that ceremonial news also plays in the stories from Prague. Great attention is lavished on Bethlen in the weeks surrounding his election. Gifts are presented to him by Frederick on eight occasions, including once when Transylvanian envoys arrived at the Bohemian court and were then dispatched home with many precious gifts, including several pistols and

12 "Extract auß einem Schreiben von Newensaal/ vom 18. Junii", untitled Zeitung (Berlin, 1620: 26); “Auß NewenSaal/ vom 18. Julii", untitled Zeitung (Berlin, 1620: 31); “Auß Leutsch/ vom 6. Augusti, Anno 1620", untitled Zeitung (Berlin, 1620: 35). 
sabres, backswords and maces adorned with jewels. The news of the presentation was then immediately followed by the assurance that Bethlen should already have the Hungarian crown in his hands. ${ }^{13}$ The honour of the gifts accompanied the belief that Bethlen would use his newfound prestige and resources to further aid the Bohemian king, as an earlier report from the city had already conveyed that Bethlen wanted the Hungarian crown not for himself, but in order to help the Elector Palatine. ${ }^{14}$ The positions of Frederick and Bethlen were not dissimilar: they are both minor rulers elected by Protestant diets in defiance of Habsburg claims to the kingships. By presenting Bethlen with increased standing, the reports from Prague not only support a close ally but indirectly reassert the legitimacy of their own new ruler.

The desire to promote the diplomatic and political ties between the Bohemian king and the Transylvanian prince are further demonstrated in the reports surrounding the other major event in the Prague news: the baptism of Frederick's son Rupert and Bethlen's position as godfather. Though Bethlen himself was not able to attend the event, he sent his representative Imre Thurzó. There are descriptions of the Transylvanian arrival, the procession into the church, the presents given and the subsequent banquets. ${ }^{15}$ In addition to the news of Bethlen's anticipated and actual election and the baptism of Frederick's son, there are items which describe the more quotidian ceremony of the Bohemian court, including the arrival of Transylvanian envoys traveling with many men and horses. ${ }^{16}$ The reporting of ceremony in the news from Prague in 1619-21 spends a large number of words to establish the allied Transylvanian and Bohemian leaders as important political and diplomatic figures, and as a result, Bethlen benefits from a flattering portrayal.

13 This news anticipated the actual election by nearly a year. "Auß Prag vom 13. Octobr", Wöchentliche Zeitungauß mehrerley örther (Hamburg, 1619: Sss).

14 “Auß Prag vom 5. October", Wöchentliche Zeitung auß mehrerley örther (Hamburg, 1619: Rrr).

15 Thurzó's arrival appears in “Auß Prag vom 15. Martio", Wöchentliche Zeitung auß mehrerley örther (Hamburg, 1620: 12); “Auß Prag vom 1. April”, Wöchentliche Zeitung auß mehrerley örther (Hamburg, 1620: 15); "Aus Praag/ vom 1. Aprillis", Aviso Relation oder Zeitung (Wolfenbüttel, 1620:15). The procession into the church appears in "Auß Prag vom 1. April", Wöchentliche Zeitung auß mehrerley örther (Hamburg, 1620: 15). Presents are described in "Aus Praag/ vom 17. Aprilis", Aviso Relation oder Zeitung (Wolfenbüttel, 1620: 17); "Auß Prag/ vom 17. April", Wöchentliche Zeitung auß mehrerley örther (Hamburg, 1620: 17). Banquets are described in "Prag vom 24. Aprilis", Die ... Zeitung/so sich in ... zugetragen hat (Hildesheim, 1620: 19); “Auß Prag vom 27. Ditto [Apr.]", untitled Zeitung (Frankfurt, 1620: 18); “Auß Praga/ vom 28. Aprilis", untitled Zeitung (Berlin, 1620: 18).

16 Examples of Transylvanian envoys at court include "Auß Praga/ vom 11. October", untitled Zeitung (Berlin, 1619: 41); “Auß Praga/ vom 29. Junii", untitled Zeitung (Berlin, 1620: 27). 
The news from the other hereditary lands does not employ ceremonial language as frequently as Prague, but presents the Transylvanians primarily as capable leaders deserving of praise and commanding strong armies. As these reports often came from the regions where the armies were marching or directly from the camps themselves, they convey a primarily military sensibility. A letter from Count Thurn describing the arrival of Transylvanian troops led by Ferenc Rhédey is particularly flattering. Rhédey, described as a "free, brave man", arrives with 12,000 men on horse and Thurn reports that he gave all possible deference. ${ }^{17}$ Stories from the hereditary lands testify to the military strength and skill of the Transylvanians rather than championing their political or diplomatic standing.

The ceremonial news from these three reporting regions-Hungary testifying to Bethlen's legitimacy, Prague to his political and diplomatic strength and the hereditary lands to the Transylvanian military ability—all stand in contrast to the stories from Vienna. The reports from this city, the capital of Transylvania's adversary in the years 1619-21, show little inclination to increase Bethlen's prestige. In general, ceremonial news is much less common in these reports, appearing in only $6 \%$ of the total stories, as opposed to the $21-23 \%$ frequency included from Prague and Hungary. The instances that do occur are much milder: Bethlen holds a banquet for the Elector Palatine and Hungarian lords, the Ottomans offer their congratulations to the Emperor, and Bethlen is presented with gifts, though they are not described in detail. ${ }^{18}$ Twice the arrival of Transylvanian envoys in fine carriages adorned in red and gold velvet appear in the reports, but even within the news of Transylvania, the envoys are more likely to be arriving from France, Hungary or the Ottoman Empire. ${ }^{19}$ While ceremonial news is not completely absent from the Viennese reports, it is considerably less frequent and as likely to focus on the role of the Viennese court

17 "Copia Schreibens an die Herrn Directores, de dato Newmühl 13. Octobris", untitled Zeitung (Berlin, 1619: 43).

18 The banquet is mentioned in "Auß Wien vom 27. Octobr" Die ... Zeitung/so sich in ... zugetragen hat (Hildesheim, 1619: 47). Congratulations are offered in "Auß Wien vom 18. Martii", Die ... Zeitung/so sich in ... zugetragen hat (Hildesheim, 1620: 14). "Stately presents" appear in "Aus Wien vom 19. Januarii", Die ... Zeitung/ so sich in ... zugetragen hat (Hildesheim, 1620:6).

19 "Aus Wien vom 27. Mai", Die ... Zeitung/so sich in ... zugetragen hat (Hildesheim, 1620:24); "Auß Wien vom 27. Ditto [May]", untitled Zeitung (Frankfurt, 1620: 23); “Auß Wien vom 10. Aprill Anno 1619", untitled Zeitung (Stuttgart, 1619: XVI); “Auß Wien/ vom 28 Decembr", untitled Zeitung (Berlin, 1620:2); "Käyserlich Mayestät Schreiben/ denen so der Augßpurgischen Confession zugethan unter Euserischen Landständen zu zustellen", Wöchentliche Zeitung auß mehrerley örther (Hamburg, 1620: 26). 
as to relate information which would contribute to the dignity of the Transylvanians.

Unfortunately for György I, the news of his march is told almost entirely through the stories from Vienna, and once again the city was not eager to present the Transylvanian leader as possessing much strength or wealth. Within these stories the Transylvanian prince does not receive a single gift, but rather sends them to the Ottomans, the Emperor and the kings of Sweden and Poland ${ }^{20}$ He does successfully host a banquet for the Ottomans and French in Kaschau to celebrate an alliance, but an earlier attempt to celebrate a victory with a feast in Castle Murány ends with a devastating attack by the Imperial forces and the slaying of many Transylvanian men. ${ }^{21}$ When wealth and power are displayed it more likely to compliment the Imperial side, as gifts are exchanged between the Emperor and the Sultan, and the Imperial commander presents captured ensigns at court. ${ }^{22}$

The 14 references to ceremony in the Viennese reports are supplemented by only a handful of items from the other reporting regions. The few reports from Hungary offer no examples of ceremonial processions, presents, hosting or address, as in the years since Bethlen's first march many Magyar noble families had reconverted to Catholicism and were not as eager to greet a Transylvanian prince promising increased rights for the Protestants. The hereditary lands offer only two references: one, a description of an Imperial ambassador to the Ottomans and the other, a compliment bestowed on a Transylvanian commander noting that is he is a sensible and good soldier. ${ }^{23}$ Though there are news reports from the Swedish headquarters in the German Lands, the relationship between the Transylvanian prince and his allies in $1643-5$ was significantly different than it was in 1619-21. While Frederick and Bethlen were in similar positions, both trying to gain more political power, the Swedes looked

$20 \quad$ "Aus Wien vom 19. Martii", Post/Hamburger und Reichs-Zeitung (n.p., 1644: 13); "Wien/ den 2. Aprilis/ St.N”, Ordinari Wochentliche PostZeitungen (Erfurt, 1644: 29); "Wien den 16. dito [July]", Wochentliche Ordinari-Post-Zeitungen (n.p., 1645: 35); "Wien den 20. dito [July]", Wochentliche Ordinari-Post-Zeitungen (n.p., 1644: 31). "Aus Wien vom 19. 29. Dito [July]", Post/ Hamburger und Reichs-Zeitung (n.p., 1645: 30); "Wien vom 24. Augusti", Wöchentliche Zeitung (Leipzig, 1644: 165).

22 Presents are exchanged in "Zeitung auß Wien/ vom 27. Aprilis/ 1644", Relation Aller Fürnemmen und gedenckwürdigen Historien (Strasbourg, 1644: 19); "Aus Wien 21.31. Augusti", Post/ Hamburger und Reichs-Zeitung (n.p., 1644: 37). Ensigns are presented in "Aus Wien vom 13. 23. Junii", Post/ Hamburger und Reichs-Zeitung (n.p., 1644: 28); "Ein anders auß Wien/ vom 5. April", untitled Zeitung (Frankfurt, 1645: XVI).

23 "Prag/ den 6. 16. Aprilis", Ordinari Wochentliche PostZeitungen (Erfurt, 1644: 33); "Iglaw vom 24. dito [May]", Wöchentliche Zeitung (Leipzig, 1645: 107). 
to György I as a helpful distraction on their enemy's southern border and did not need him to bolster their political legitimacy in the region. The one item of ceremonial news in these reports, therefore, does nothing to advance the political or diplomatic standing of the Transylvanian, but is merely a reference in a report from Berlin that discussions with György I would be suspended until after a feast. ${ }^{24}$ As a result, the news of György I contains little reference to the demonstrations of wealth and power that ceremony could offer, and the prince himself seems considerably weaker as a result, more a pawn than a player. Despite how the legacies of Bethlen and György I may appear in the news, the end result of both princes' marches into Hungary were similar: both settled with the Emperor along the terms of the Peace of Nikolsburg, gaining the lands of some counties and concessions for the religious practices of the Protestants. However, because of the particular motivations of the reporting regions, Bethlen was the subject of not only twice as many news stories as György I, but also over five times more items of ceremonial news.

While György II experienced political consequences far more disastrous than the apathy that greeted his father's march on Hungary, he also benefited from ceremonial news from the embattled lands of Poland-Lithuania. Though references to ceremony only occur in $13 \%$ of the reports from the region, they nevertheless present the prince as a capable leader, as when he receives Cracow's key to the city and is described as a stately, humble and brave prince. ${ }^{25}$ Additionally, the Transylvanian-Swedish alliance is highlighted in György II's hosting of the Swedish king at a banquet and the Transylvanian's presentation to his ally of fine horses and saddles. ${ }^{26}$ News from the Baltic and the hereditary lands continued to emphasise this relationship with more gifts presented and the hosting of officers from both armies in Cracow. ${ }^{27}$ Though György II's Polish

24 "Aus Berlin vom 3. 13. Januarii. 1645", Post/ Hamburger und Reichs-Zeitung: Zu Num ... gehörige (n.p., 1645: 1).

25 "Crakow vom 4. April", Wöchentliche Zeitung auß mehrerley örther: Diengstags (Hamburg, 1657: 17); "Crakow vom 5. April”, Wöchentliche Zeitung auß mehrerley örther: Donnerstags (Hamburg, 1657: 17).

26 "Eigentlicher und glaubwürdiger Bericht/ wann und wo Ihre Königl. Majest. zu Schweden rc. rc. sich mit des Herrn Ragotzi Hochfürstl. Durchl. in Pohlen conjungiret/ und was dabey vorgangen/ sub dato in dem Königl. Schwedischen Hauptquartier Zavichost den 6. Aprilis Anno 1657", Wöchtenliche Zeitung auß mehrerly örther: Donnerstags (Hamburg, 1657: 21); "Ein anders [Zawichost] vom 7. Dito [Apr.]", Wöchtenliche Zeitung auß mehrerly örther: Donnerstags (Hamburg, 1657: 21).

27 "Extract Schreibens aus Riga vom 10. 20. Dito [Apr.]", Wöchentliche Zeitung auß mehrerley örther: Appendix (Hamburg, 1657: 18); “Auß der Schlösien/ vom 24. April”, Relation Aller Fürnemmen und gedenckwürdigen Historien (Strasbourg, 1657: 18). 
incursion would ultimately end in disaster, for a few months in 1657 , he was represented as the capable leader of an army with strong allies.

Once again, the ceremony in the news from Vienna continued to concentrate on the diplomatic importance of the city, with general descriptions of ostentatious arrivals of envoys and gifts presented to the Emperor by György II. ${ }^{28}$ However, there are also two references to a gift made to the prince by the Emperor, a portrait on a gold chain valued at 1,00o ducats, demonstrating a diplomatic relationship not as readily expressed when the Transylvanians were marching into Hungary. ${ }^{29}$ With György II's return to Transylvania in disgrace, however, the laudatory ceremonies disappear. Though the election of two new princes was reported from Transylvania, these events are not characterised as a cause for celebration, but rather as demonstrations of the increasing weakening of the principality's autonomy. Therefore, no ceremonial occurrences are related with the news.

The German language newspapers offer an opportunity to examine a variety of perspectives on a particular subject, as news was communicated not only from the region where an event took place, but also in stories from the participants' allies and enemies. This diversity of perspective is, on the whole, beneficial for the subject of the news. In the case of the three Transylvanian princes considered here, the greater the breadth of reporting locations, the more likely it was that the prince would be described within the context of ceremonial events, associating him with greater prestige and power. Though the military exploits of György II Rákóczi led to a political nightmare for the principality of Transylvania, during the march into Poland he was still portrayed as a brave prince with strong allies backing him and military conquests under his belt because that is how the story was told by cities in Poland, Silesia and along the Baltic. György I Rákóczi's march into Hungary may have won concessions from the Emperor, but the only location to offer a large quantity of reports was Vienna, a city which was more likely to include ceremonial occurrences which glorified the Emperor than those which celebrated his Transylvanian

28 Envoys arrive in "Aliud ab eodem [Vienna 2 Oct.]", Wöchentliche Zeitung auß mehrerley örther: Donnerstags (Hamburg, 1658: 42); “Wien vom 2. 12. [Apr.]”, Wöchtenliche Zeitung auß mehrerly örther: Donnerstags (Hamburg, 1657: 17). György II gives the Emperor 12 fine horses in "Auß Wienn/ vom 18. Dito [Sept.]", Ordinari Zeitung (Munich, 1658: 39); "Aus Wien vom 17. Septemb", Wöchtenliche Zeitung auß mehrerly örther: Donnerstags (Hamburg, 1658: 40); “Wien vom 28. Dito [Aug.]", Wöchentliche Zeitung auß mehrerley örther: Donnerstags (Hamburg, 1658: 37).

29 "Wien vom 20. 30. Jan”, Wöchtenliche Zeitung auß mehrerly örther: Appendix (Hamburg, 1657: 5); "Wien vom 8. 28. [sic] Dito [Jan.]", Wöchtenliche Zeitung auß mehrerly örther: Donnerstags (Hamburg, 1657:5). 
antagonist. By far the most celebrated prince of the three, Bethlen Gábor, was dignified with a great deal of ceremonial news not only because of the political and diplomatic successes of being elected king of Hungary and named godfather to the king of Bohemia's son, but also because the reporting regions of Hungary and Prague benefited from portraying each of these events in a grand manner, full of processions, presents and banquets.

Each of these diverse perspectives are displayed within the newspaper reports, and by following a story or subject, rather than a particular publication or city, these variations become more apparent. This method is particularly useful when examining a region, such as Transylvania, that rarely reported news of the adventures of its own princes, but can also lead to fruitful analyses of other, more popular topics. Reporting locations can offer information not only on changing infrastructure of news networks, but also serve as guides to interpreting variations within the content of the news stories. 